\title{
ARTIGOS
}

\section{PLATONISMO E ARISTOTELISMO NO SÉCULO XII (II).}

\author{
RUY AFONSO DA COSTA NUNES \\ Professor-assistente do Setor de Filosofia e História \\ da Educação. Departamento de Educação da Faculdade \\ de Filosofia, Ciências e Letras da Universidade de \\ Sâo Paulo.
}

\section{CAPITULO III.}

\section{A AlMA DO MUNDo No PENSAMENTO DO SÉCUlO XII.}

Passo agora a examinar, à guisa de ilustração do platonismo no século XII, as concepções de alguns de seus pensadores a respeito da Alma do Mundo. Antes, porém, de efetuarmos tal exame, convém analisar a concepção original de Platão, bem como as que foram formuladas por Plotino e Macróbio. Como, além disso, o conceito de Alma do Mundo sofreu a interpretação cristã de Calcídio em seu Comentário ao Timeu, examinarei ao pé da letra o que êle diz nesta obra, respigando, em seguida, algumas alusões de Boécio a tal tema, com o que estaremos aptos para apreciar as metamorfoses a que se sujeitou o conceito de Alma do Mundo, desde Platão até os doutores do século XII. Evidentemente, não vou fazer um estudo sôbre as peripécias de tal conceito no decurso da história do pensamento antigo. O que me interessa é considerá-lo entre os primeiros escolásticos, e para isso se faz mister remontar aos autores que os influenciaram, conforme o que ficou estabelecido no capítulo anterior (77).

Seguindo à risca o Timeu (34a-37c), a Alma foi colocada no centro do corpo do mundo, estendendo-se através dêle, e ainda além, a envolvê-lo completamente. Foi formada antes do corpo, sendo anterior a êle pela idade e pelo poder, pois a ela compete mandar e ao corpo obedecer. O Demiurgo formou-a por meio da combinação da natureza do Mesmo, da natureza do Outro, e da terceira substância, resultado da mistura do Mesmo e do Outro. Assim composta,

(77) . - A respeito da Alma do Mundo em Macróbio e Calcidio consulte-se Fraile, O. P., História de la Filosofia, I GRECIA Y ROMA, 
foi dividida e unificada matemàticamente. Ela se move por si própria em círculo, girando sôbre si mesma. O número é o elemento mais importante em sua constituição. No interior da Alma foi incluído tudo quanto é corpóreo, ficando corpo e alma em perfeita harmonia .

Segundo Plotino, acima e fora da realidade inteligivel e material, antes de qualquer cousa, encontra-se o Uno, inefável, a primeira Hipóstase ou Princípio, fonte original de tudo quanto existe:

\footnotetext{
"Antes da luz, está uma outra luz que irradia sôbre o inteligível, permanecendo imóvel" (78).
}

Do Uno, "como a luz que emana do sol", procede a Inteligência, a segunda Hipóstase, que constitui o mundo dos inteligíveis, os modelos abstratos do mundo sensível. A Inteligência é o próprio ser, a pura forma subsistente, a essência de tôdas as coisas. A Inteligência pensa a si própria, conhece a si mesma na contemplação do Uno, e produz a terceira Hipóstase, que é a Alma do Mundo. O corpo do mundo une-se à Alma Universal, e é como que iluminado por ela, sem que ela se embarace ou se preocupe com isso (79). A Alma tem um lado inferior voltado para o corpo e um lado superior voltado para a Inteligência. A Alma organiza o universo pela parte que está do lado do corpo, pela sua parte inferior (80). A Alma que tudo administra, ordena e domina,

"é una, como una é sua obra" (81).

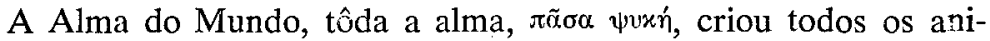
mais terrestres, aquáticos e aéreos, e no céu os astros divinos, o sol, e o céu imenso, que ela ordenou e ao qual imprimiu movimento de rotação regular. Ela possui natureza diferente dos sêres que ela ordena, move e faz viver; não é perecível como êles, mas existe sempre. O mundo sem alma não passa de corpo inerte, terra e água, matéria obscura, um não-ser. A alma é que the dá vida, a imortalidade. Graças a ela, êste mundo é uma divindade (82).

Segundo Macróbio, de Deus ao limo da terra existe profunda conexão entre tôdas as coisas; a Inteligência nasceu do Deus supremo e a Alma nasceu da Inteligência. E' a Alma que cria e anima os

\footnotetext{
(78) . - Plotino, ENéada V, 3, 12.

(79) . - Plotino, ENEADA III, 4, 4.

(80) . - Plotino, ENEADA IV, 8, 8.

(81). - Plotino, ENEADA IV, 4, 10.

(82). - Plotino, ENEADA V, 1, 2.
} 
sêres vivos e seu resplendor é refletido por todos os sêres (83). Deus, causa primeira, é o princípio e a fonte de tudo quanto existe. Ele engendrou a Inteligência. Esta, enquanto contempla seu pai, conserva plena semelhança com êle, mas produz a Alma, ao olhar para trás. A Alma, por sua vez, enquanto contempla a Inteligência, reproduz os seus traços, mas quando afasta dela o olhar, ela, que é incorpórea, degenera na formação dos corpos. Da Inteligência ela recebeu a puríssima razão, mas também possui, por natureza, o poder de dotar os corpos com os sentidos e o crescimento. A razão é absolutamente divina e, por isso, só convém aos sêres divinos. Os dois outros poderes, os sentidos e o crescimento, cabem aos sêres perecíveis.

Em outro passo de seu Comentário, Macróbio descreve a formação da Alma do Mundo segundo Platão (84).

A concepção da realidade apresenta-se em Calcídio como um platonismo reformado, interpretado à luz da doutrina cristã, embora nem sempre o autor se exprima com clareza e precisão. O Demiurgo de Platão é substituído por Deus, ser transcendente e absoluto, criador do mundo sensível, da Alma Universal e do homem. Em Calcídio deparamos com a concepção de Alma do Mundo, que será reproduzida séculos mais tarde por Bernardo Silvestre em seu De Mundi Universitate. Para o Comentador do Timeu, a Alma do Mundo não é, como em Platão, um ser divino, mas uma espécie de energia conferida por Deus aos seres materiais, e que determira suas diferenças específicas e propriedades típicas, ou seja, é Ela o princípio do mo-

(83). - Macróblo, COMMENTARIUS ex CICERONE in SOMNIUM SCIPIONIS, Lib. I, Cap. XIV - "Secundum haec ergo cum ex summo Deo mens, ex mente anima sit; anima vero et condat, et vita compleat omnia, quas sequuntur, cunctaque hic unus fulgor illuminet, et in universis appareat, ut in multis speculis, per ordinem positis, vultus unus; cumque omnia continuis successionibus se sequantur, degenerantia per ordinem ad imum meandi: invenietur pressius intuentia summo Deo usque ad ultimam rerum faecem una mutuis se vinculis religans et nusquam interrupta connexio"...

"Deus, qui prima causa et est, et vocatur, unus omnium quaeque sunt, quaeque videntur esse, princeps et origo est: hic superabuncanti majestatis fecunditaie de se mentem creavit. Haec mens, quae vo $\tilde{v}_{3}$ vocatur, qua patrem inspicit, plenam similitudinem servat auctoris: animam vero de se creat, posteriora respiciens. Rursus anima patrem qua intuetur, induitur, ac paulatim regrediente respectu in fabricam corporum, incorporea ipsa degenerat. Habet ergo et purissimam ex mente, de qua esta nata, rationem, quod hoүıxòv vocatur; et ex sua natura accipit pracbendi sensus praebendique incrementi seminarum;

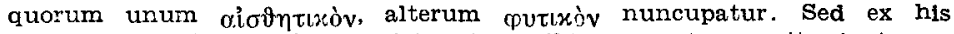
primum, id est, $\lambda_{0} \gamma$ lxòv, quod innatum sibi ex mente sumsit, sicut vere

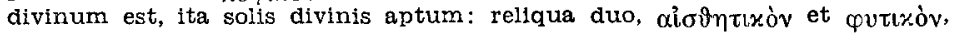
ut a divinis recedunt, ita convenientia sunt caducis".

(84) . - Macróbio, COMMentariJs... Lib. II, Cap. II. Quanto à constituição matemática cia Alma do Mundo, consulte-se Livro I, cap. VI. 
vimento, da vida, das tendências, do crescimento, da imaginação em todos os viventes e da razão no homem (85).

$\mathrm{Na}$ Consolação da Filosofia de Boécio deparamos com algumas alusões à Alma do Mundo como, por exemplo:

$$
\text { "que alma arrasta o mundo imutável" (86); }
$$

mais adiante:

\begin{abstract}
"Tu (que governas o mundo...), colocaste no centro do mundo a alma de tríplice essência, que move tôdas as coisas, e a espalhaste através dos membros harmoniosos do universo" (87).
\end{abstract}

Por último, diz Boécio que

"a Alma Universal pode urdir a trama do destino" (88).

Finalmente, na linha das influências relativas à Alma do Mundo, convém lembrar os Santos Padres. Orígenes, por exemplo, afirmava que, à semelhança do corpo humano informado por uma alma, o mundo inteiro devia ser tomado por um animal imenso, gigantesco, mantido pelo poder e pela razão de Deus, que devem ser considerados como uma Alma (89).

Num de seus Discursos Teológicos (90) diz Gregório Nazianzeno, que os mais atilados entre os gregos a pensar sôbre Deus entreviram o Espírito Santo, ao qual chamaram "a Inteligência do Universo", "a Inteligência exterior", ou deram outros nomes.

Em 1139, Guilherme de Saint-Thierry dirigiu uma carta a Godofredo, bispo de Chartres, e a São Bernardo, abade de Claraval, exortando-os a defenderem a causa de Deus e da Igreja contra os êrros de Pedro Abelardo (91). Entre as proposições, que êle retirou dos opúsculos do Mestre de Santa Genoveva, encontra-se a seguinte:

"Ele diz que o Espírito Santo è a alma do mundo".

De fato, imbuído de idéias platônicas colhidas nos escritos dos Santos Padres, e em Macróbio, e, quem sabe, no Comentário ao Ti-

(85). - CHALCIDII COMMENTARIUS in TIMAEUM PLATONIS, cap. 53.

(86) . - Boethius, PHILOSOPHIAE CONSOLATIONIS LIBRI QUINQUE, Lib. I, Metrum 2

(87). - Idem., Lib. III, Metrum 9

(88). - Idem., Lib. IV, Prosa 6, 13.

(89) . - Origenes, PERI ARCHON ou DE PRINCIPIIS, PG, T. XI, tomus primus, Lib. II, cap. III, cl. $183 \mathrm{D} / 184 \mathrm{~A}$.

(90) . -- Grégoire de Nazianze, LES DISCOURS THEOLOGIQUES, pág. 178.

(91). - Epístola 326, OEUVRES de SAINT BERNARD, T, II, trad, par Ravelet, PL 182, Ep. 320, cl. 531. 
meu de Calcídio, Abelardo era do parecer que a escola platônica sempre concordara com a fé na Santíssima Trindade (92). Ora, em tal contexto de idéias não é de admirar que a Alma do Mundo, o terceiro elemento da tríade de Macróbio: Deus, mens, anima, se afigurasse a Abelardo como o Espírito Santo (93). Platão afirmou, com tôda a razão, ser o Espírito Santo a Alma do Mundo, e como que a vida de tudo quanto existe, uma vez que tôdas as coisas são, a bem dizer, sêres viventes diante dêle, e nenhuma é morta, isto é, inútil nem má, pois tudo é disposto òtimamente graças à sua bondade. Do mesmo modo, Platão falou bem, ao dizer que a Alma é um ser misto, composto da substância indivisível em si, e da divisível pela união corpórea, isto é, sua ligação com os corpos. Essa dupla natureza da alma se revela, quando ela se aplica a criar, reger ou dispor qualquer coisa, da mesma forma que a alma sensível prodigaliza ao próprio corpo os seus benefícios. Se o Filósofo the atribuiu tôda a fôrça e harmonia proporcional dos números, êle o fêz para ensinar que a harmonia de tôdas as coisas consiste na bondade da graça divina (94). Diz êle na Teologia Cristã que a expressão Alma do Mundo, usada pelos platônicos, constituía um belíssimo símbolo do Espírito Santo, per pulcherrimam involucri figuram (95). Na Introdução à Teologia Abelardo fornece mais pormenores a respeito da questão. O Espírito Santo é a Alma do Mundo de que fala Platão. Para êste,

(92). - "Ex quo liquidum est Platonicam sectam fidel sanctae Trinitatis plurimum semper assentiri, et eam diligentius caeteris omnibus philosophts a Platone, et sequacibus ejus distingui ac describl". Abaelardus, INTRODUCTIO AD THEOLOGIAM, PL 178, cl. 1029.

E' bom sempre ter em mente a confissão de Abelardo de que ia buscar os testemunhos dos filósofos, não em seus escritos, dos quais pouco conhecia, mas na obras dos Santos Padres: "Quis etiam me testimonils philosophorum inductis ratione arguat, nisi et in culpam mecum sanctos doctores in hoc ipso trahat? Quae enim superius ex philosophis collegi testimonia, non ex eorum scriptis, quorum pauca novi, imo ex libris sanctorum Patrum collegi". INTRODUCTIO ad THFOLOGIAM, cl. 1039.

(93). - "Hanc autem animae videlicet mundanae doctrinam praecipue diligentissimus philosophorum in expositione Macrobius reliquit. Cuius verba si diligenter inspiciamus, totam fidem fere nostram de Spiritu sancto in ipsis expressam inveniemus, cum hanc ipsam animam et Creatorem nominet, atque ex Deo Fatre et Noyn, hoc est Deo filio, astruat esse". INTRODUCTIO ad THEOLOGIAM, cl. 1024 C. Sôbre a influência de Macróbio sôbre Abelardo consulte-se Sshedler, DIE PHILOSOPHIE des MACROBIUS, zweiter Teil, pág. 114 e seguintes.

(94). - INTRODUCTO ad THEOLOGIAM, cl. 1013-1016.

(95). - "IFis ex Flatone breviter collestis, atque ad nostrae fldel testimonium satis, ut arbitror, diligenter expeditis. consequens existimo ad sequaces efus commeare, ut ea quae ab ipsis quoque de anima mundi dicta sunt, nulla ratione convenienter accipi posse monstremus, nisi Spiritui sancto per pulcherrimam involucri figuram assignentur". Abaelardus, THEOLOGIA CHRISTIANA, PL 178, cl. $1152 \mathrm{C}$. 
contudo, a alma teve início, enquanto para nós o Espírito Santo é eterno. "Espírito" é nome de natureza, enquanto alma designa uma funçâao, que é indicada etimològicamente: anima... ab animando. Platão chama o Espírito Santo de alma em função das obras; nós, porém, falamos do Espírito Santo, segundo a disposição natural de sua bondade, que Ele possui eternamente. Nem sempre o Espírito Santo foi alma, isto é, vivificans, porque enquanto não existiam criaturas às quais distribuísse seus dons, Êle não podia exercer sua munificência (96) .

Outra interpretação piedosa, que Abelardo confere à Alma do Mundo, encontra-se num lanço da Introdução à Teologia. Quando Platão afirma que Deus colocou a alma no centro do mundo, estendendo-a igualmente por todo o globo do orbe arredondado, usa de uma linda expressão para designar a graça de Deus oferecida a todos os homens, uma vez que é justo e salutar tudo dispor com benignidade nesta grande casa ou templo de Deus, que é o universo (97) .

Pelo que vimos, Abelardo não identifica pura e simplesmente o conceito de alma do mundo de Platão com o Espírito Santo. Ele faz ressalvas, distingue entre o sentido temporal e cósmico da alma, e a eternidade e a natureza divina do Espírito Santo, bem como vê naquela um símbolo da realidade superior que é Este. Diz êle ainda que, segundo Macróbio, a filosofia sempre preferiu anunciar os seus segredos especialmente a respeito da alma e dos deuses, não de maneira explícita, mas através de símbolos, recorrendo até mesmo a fábulas. Assim se deve entender o que diz Macróbio sôbre a Alma do Mundo. Do contrário, seríamos levados a pensar que Platão foi o maior estulto que já existiu. Que haveria de mais ridículo que pensar

(96). - INTRODUCTIO ad THEOLOGIAM, cl. 1080-1085; THEOLOGIA CHRISTIANA, cl. $1309 \mathrm{~B}$.

(97). - "Illud quoque quod ait Plato, animam lccatam esse a Deo in medietate mundi, eamque per omnem globum teretis orbis aequaliter porrigi, pulchre designat gratiam Dei omnibus communiter oblatam, cuncta prout salubre vel aequum est, kenigne in hac magia como sua seu templo disponere". INTRODUCTIO ad THEOLOGIAM, cl. 1.018.

Quero chamar a atenção do leitor, de passagem, para a semelhança entre as expressóes usacas por Abelardo neste texto e as da tradução de CaIcídio, CHALCIDII TIMAEUS ex PLATONIS DIALOGO TRANSLATUS, \$ 12: "Animam vero in ejus medietate locavit, eandemque per omnem globum aequabiliter porrigi jussit: que tectis interioribus partibus, extima quoque totius corporis ambitu animae circumdarentur. Atque in orbem teretem in orbem atque in suum ambitum voluit converti et moveri". Isso pode ser indício de que Abelardo leu a tradução de Calcídio, ou pelo menos teve sob os olhos algum excerto dela, possivelmente numa antologia. 
o mundo como animal racional, a não ser que se entenda isso como um disfarce, nisi hoc per integumentum sit prolatum? (98) .

Na Epitome Theologiae Christianae, que São Bernardo chamou de Sentenças de Abelardo, mas que não foi escrita pelo filósofo e sim por algum discípulo, o capítulo XVIII é consagrado aos

"filósofos que designam o Espírito Santo por alma do mundo" (99) .

Aliás, a obra é um resumo da Introductio ad Theologiam (100).

Outro autor do século XII que discorre sôbre a Alma do.Mundo é Bernardo de Chartres em sua obra, de fina lavra literária, De Mundi Universitate, na qual a prosa alterna com a poesia, escrita em latim rebuscado e que ainda hoje constitui leitura interessante. Sôbre êle e seu trabalho escreveu Gilson um artigo valioso (101), procurando demonstrar que Silvestre não foi mitólogo como os antigos gregos (tese de Barach), nem precursor de Giodano Bruno (Victor Cousin), nem partidário da filosofia panteísta (Clerval), nem um simples pagão (Poole), nem um pagão que teve algumas relações com o Cristianismo (L. Thorndike). Gilson demonstra meridianamente que Bernardo foi um humanista verdadeiramente cristão, e que sua obra não é um tratado de física ou de metafísica, mas uma cosmogonia poética de fundo cristão e forma pagã. No conjunto seria um comentário da obra dos seis dias, um In Hexaemeron. Segundo Manitius, Bernardo identificou a Alma do Mundo com o Espírito Santo (102). Parece-me que tal afirmação não procede, uma vez que da

\footnotetext{
(98). - "Quantum etiam semper philosophia arcana sua nudis publicari verbis dedignata sit, et maxime de anima, et de dis, per fabulosa quaecam involucra loqui consueverit, ille non mediocris philosophus et magni philosophi Ciceronis expositor Macrobius diligentissime docet". THEOLOGIA CHRISTIANA, cl. $1153 \mathrm{C}$.

"Ex hac itaque Macrobil traditione clarum est, ea quae a philoscphis de anima mundi dicuntur, per involucrum accipienda esse: alioquin summum philosophorum Platonem summum stultorum esse deprehendemus. Quid enim magis ridiculosum, quam mundum totum arbitrari unum animal rationale, nisi hoc per integumentum sit prolatum?" THEOLOGIA CHRISTIANA, cl. $1.155 \mathrm{~A}$.

(99). - "Sententiae Hermani... que nấo foram escritas antes de 1139", corrige Landgraf em INTRODUCCTON a la HISTORTA de la LITERATURA TEOLOGICA de la ESCOLASTICA INCIPIENTE, păg. 108.

(100) . - O nome certo da obra, comumente chamada Introductio ad Theologiam, é THEOLOGIA SCHOLARIUM, Landgraf, idem, pág. 104.

(101) . - Gilson, LA COSMOGONIE de BERNARDUS SiLVESTRIS in Arch:ves d'Histoire Doctrinale et Littéraire du Moyen Age, t. III, págs. 5-24.

(102). - "Der Noys ist dem Logos und die Endelechia oder Weltseele dem hl. Geiste gleich". Manitius, GESCHICHTE der LATEINISCHEN LITERATUR des MITTELALTERS, III, pág. 206. Mesma opreciação em Ueberweg/ Heinze, GRUNDRISS der GESCHICHTE der PHILOSOPHIE, Band II, pág. 237.
} 
obra de Bernardo pode-se distinguir claramente a Trindade divina da tríade cósmica de que participa Endelechia ou a alma do mundo. E' verdade também que o próprio Bernardo ensejou tal interpretação com suas expressões dúbias. E' preciso, outrossim, não perder de vista que o fundo cristão da obra de Silvestre está emoldurado por alegorias de origem pagã, à moda mitológica dos antigos poetas .

Divide-se a obra em duas partes: o Megacosmo em que o autor descreve a ornamentação do mundo, e o Microcosmo em que apresenta a criação do homem. Na primeira encontra-se uma poética concepção da Santíssima Trindade. O tom religioso da passagem é indicado pór uma referência anterior à crença religiosa. Depois de procurar Urania entre as estrêlas, Natura chega às regióes supernas em que se encontra o sacrário do Deus supremo e essencial, "se acreditas nos argumentos teológicos". Deus Pai é o Sumo Bem, Tugaton, têrmo tomado de empréstimo a Macróbio (103), que adota a expressão grega tó agathón, o Bem, para designar Deus Todo Poderoso, soberano dos outros deuses. Do trono em que se assenta Tugaton desprende-se uma irradiação refulgente, infinita e eterna. Essa luz inaccessível ofusca os olhos de quem a contempla, perturba a vista. Dessa irradiação infinita e eterna deriva um segundo raio e dêsses dois primeiros brota o terceiro. Para significar a identidade de essência das Três Pessoas diz Bernardo que todos os raios são uniformes, de claridade igual, e, que ao iluminarem tôdas as coisas, se confundem novamente na vastidão da sua fonte (104). Essa alegoria da Santíssima Trindade oferecida por Bernardo Silvestre lembra a do sol, esplendor e calor, usada por Abelardo para ilustrar com uma comparação os têrmos em que é proposto o mistério (105). Noys, personagem central no De Mundi Universitate, equivale ao Verbo, segunda Pessoa da Santíssima Trindade. Noys, é a razão de Deus, da mesma essência que Ele e por Êle gerada eternamente (106). Em Noys en-

(103) - - Macrobius, COMMENTARIUS ex CICERONE in SOMNIUM SCIPIONIS, Lib. I, cap. II.

(104). - "Fx sedibus quidem, quas Turaton suprema divinitas habitatrix insistit, splendor emicat radiatus, non utique perfunctorius, sed infinibllis et aeternus. Ea igitur lux inaccessibilis intendentis reverberat oculos, aciem praeconfundit, ut quia lumen se defendit a lumine, splendorem ex se videas caliginem peperisse. Ex splendore igitur vel infinibili vel aeterno alter se radius exetebat, ut ex primo secundozue suboriretur et tertius. Qui quidem radii uniformes et claritatis parilitate consimiles cum omnia collustrassent, se rursus sui fontis liquoribus admiscebant". Bernardi Silvestris DE MUNDI UNIVERSITATE LIBRI DUO sive MEGACOSMUS et MICROCOSMUS, pág. 41, 1. 23-33. O 1, após o número da página, indica a linha.

(105) . - Abaelardus, INTRODUCTIO ad THEOLOGIAM, cl. 1070.

(106) . - "Porro noys ego, Dei ratio profundius exxuirita, quam utisue de se alteram se usia prima genuit, non in tempore, sed ex eo quo consistit aeterno... Sua rerum nativitas, divina prior celebratur in mente, se- 
contram-se as idéias divinas, que são realizadas pela ação criadora. Nela se acham os modelos dos viventes, as idéias eternas, o mundo inteligivel, o conhecimento determinado das coisas (107). Distinta da Trindade divina apresenta-se a tríade cósmica de Endelechia, $\mathrm{Na}$ tura e Imarmene. Endelechia é a Alma do Mundo; Natura, a natureza,

\author{
"filha da providência que não deixa de ser providência para o \\ mundo e para as coisas",
}

que produz os corpos, é, como diz Noys,

"a bem aventurada fecundidade do meu útero" (108).

Imarmene, têrmo estóico, significa o destino,

"continuação do tempo constituída para a ordem",

que tece a trama do universo (109).

O tema do De Universitate é exposto pelo autor no Breviarium, sinopse, logo no início da obra. Natura dirige-se a Noys, providência de Deus, queixando-se em lágrimas da confusão da matéria e suplicando-lhe que afeiçoe o mundo, tornando-o mais belo. Noys atende ao seu pedido, e no Megacosmo promove a ornamentação do mundo. Separa os quatros elementos uns dos outros, coloca no céu as nove hierarquias angélicas, fixa as estrêlas no céu, ordena o curso dos sete planêtas, opõe uns aos outros os quatro ventos cardinais e distribui pela terra os montes, rios, árvores, ervas, plantas, flôres, peixes, aves, animais.

No Microcosmo, Noys fala à Natura gloriando-se do embelezamento do mundo e promete formar o homem para completar a sua obra. Em suas iniciativas, Noys é secundada por Endelechia, Natura, Urania e Physis com suas duas filhas Theoria e Practica.

Da fonte de luz que é Noys surge, como por emanação, Endelechia, vida e esplendor das coisas. Tem a forma de um grande globo

\footnotetext{
cunda est quae sequitur actione". Bernardus Silvester, DE MUNDI UNIVERSITATE, pág. 9, I. 6-8 e 13-15.

(107). - "Ea 1gitur noys summi et exsuperantissimi Del est intellectus et ex eius divinitate nata natura. In qua vitae viventis imagines, notiones aeternae, mundus intelligibilis, rerum cognitio praefinita". Idem, pág. 13, 1. 152155.

(108). - "Cum ad loquentem oculos vultu noys sustulit blandiore et quasi mentis penetralibus foris evocato colloquio: Vere, inquit, et tu natura, uteri mei beata fecunditas, nec degenerans nec decedis origine, quae filia providentiae mundo et rebus non desinis providere". Idem, pág. 9, 1. 1-6.

(109) . - "Imarmene quae continuatio temporis est ad ordinem constituta, disponit texit et retexit quae complectitur universa". Idem, pág. 32, 1. 126.
} 
de âmbito limitado, globus terminatae quidem continentiae. Isto significa que não se trata de uma essência infinita, como é o Espírito Santo; isto é clara indicação de que não corresponde a um raio pro. veniente da luz infinita e eterna, embora seja de natureza espiritual, o que se infere da passagem sed quam non oculis verum solo pervideas intellectu, ou seja, êsse globo imenso e limitado não pode ser percebido pela vista, mas só pela inteligência. Todavia, sua clara substância de fluido transparente, diz Silvestre, apresenta a imagem da sua fonte. A Alma do Mundo, Endelechia, parece mais parenta do ar e do céu, mas está presente em cada uma das partes do universo. Ela é o princípio fecundante da matéria, o princípio que transmite aos sêres inferiores a chama da vida, que ela mesma recebeu por infusão do espírito. Essa vida vegetal ou animal que ela distribui, é transmitida aos sêres aptos para recebê-la, de acôrdo com sua capacidade (110). A fôrça de Endelechia, sua afinidade com as estrêlas e com o céu persistem, enquanto ela conforta os sêres celestiais das regiões supernas; quando, porém, ela se relaciona com os sêres inferiores, seu poder degenera, sua fôrça decai. Em suma, a Alma do Mundo surge como por emanação da fonte luminosa que é Noys; só é perceptível pelo intelecto na forma de um grande globo limitado; transmissora da vida que ela mesma recebe "de spiritus infusione", é princípio fecundante da matéria para a multiplicação ordenada das coisas (111). Com tais indicações, ainda se fica em dúvida sôbre a verdadeira natureza da Alma do Mundo segundo Bernardo Silvestre. Surge por emanação de um ser infinito, mas tem natureza finita; tem a forma de um globo imenso, mas é espiritual; distribui a vida para todos os viventes, mas degenera em contacto com os inferiores...

No fim do Megacosmo Bernardo Silvestre resume as relações da tríade cósmica com Noys, o intelecto divino, e especifica ainda mais as funções de Endelechia. Noys transmite à Endelechia as idéias divinas, a qual as trnsmite para Natura e esta as passa para Imarmene com as normas para sua realização (quid mundo debeat). Endelechia fornece a substância das almas; Natura confecciona seus habitáculos, que são os corpos e Imarmene tece a trama do destino universal (112).

\footnotetext{
(110). - "Ubi igitur animae mundique de consensu mutuo societas intervanit, vivendi mundus nactus originem quod de spiritus infusione susceperat, mox de toto reportavit ad singuia eo vitae vegetationis genere, cui pro captu proprio fuerant aptiora". Idem, pág. 14, I. 199-203.

(111). - "Itaque viventis animae beneficio confortata de nutricis silvae gremio se rerum universitas et series explicavit". Idem, pág. 15, 1. 210-212.

(112) . - "Sicut enim divinae semper voluntatis est praegnans, sic exempli aeternarum quas gestat imaginum noys endelechiam, endelechia naturam, natura imarmenem quid mundo debeat informavit. Substantiam animis endelechia subministiat, habitaculum animae corpus artifex natura de
} 
Na segunda parte, Microcosmo, Urania, Physis e Natura são incumbidas por Noys de prepararem o homem. A cada uma coube uma tarefa: a composição da alma, das virtudes e do corpo do homem. A Urania competiria tomar a semente da alma humana da substância já criada de Endelechia (113). existe.

Para Guilherme de Conches a filosofia estuda tudo quanto

"É a verdadeira compreensão da realidade invisível (eorum quae sunt et non videntur) e da realidade visível (eorum quae sunt et videntur)".

Existem e são invisíveis os sêres incorpóreos, como Deus Uno em essência e Trino em pessoas, a Alma do Mundo e os Demônios, sêres espirituais entre os quais existem os bons e os maus, os kalodaimones e os kakodaimones (114).

No De Philosophia Mundi, ao tratar da Alma do Mundo, Gujlherme apresenta as três opiniões existentes no século XII a respeito dela. Primeiramente há os que confundem a Alma do Mundo com o Espírito Santo. Tudo o que vive no mundo, vive pela vontade e pela bondade divina, que é o Paráclito.

Em segundo lugar, estão os que consideram a Alma do Mundo como o vigor natural conferido por Deus às coisas e pelo qual certos sêres vivem, sentem e conhecem. Não há ser vivo, sensível e pensante no qual não exista êsse vigor ou energia.

Conforme a terceira opinião, a Alma do Mundo é uma substância incorpórea, que existe em cada corpo, ainda que não exerça as mesmas funções em todos devido à rudeza de alguns. Ora, o homem tem sua própria alma. Então nêle existem duas, pode alguém concluir. A isso responde Guilherme que a Alma do Mundo não é pura e simplesmente a Alma, sicut non dicimus caput mundi esse caput. Lembra aí o ensinamento de Platão, segundo o qual a alma deve ser pensada como um ser duplamente composto pela substância divisível

initiorum materis et qualitate componit. Jmarmene quae continuatio temporis est sed ad ordinem constituta, disponit texit et retexit quae complectitur universa". Idem, pág. 32, 1. 120-128.

(113). - "Trina igitur tribus incumbit opera cuique sua: compositio animae ex endelechia et virtutum aedificatione, corporis ex materiae praeraratione. Utrorumque corporis et animae formativa concretio de caelestis ordinis aemulatione. Prior Igitur ad Uraniam, secunda ad Physin, tertia ad te, o Natura, dinoscitur pertinere. Verumtamen indultum vobis plurimum, vestro plurimum destractum est operi. In vestra manu est sumere cum velitis humanae sementem animae ex endelechia iam creatam". Idem. pág. 56, 1. 1-9.

(114). - Guilherme de Conches, DE PHILOSOPHTA MUNDI, Lib. I, cap. XV. PL 172 (sob o nome de Honório de Autun), cl. $46 \mathrm{C}$ e seguinte. 
e indivisível, com natureza identica e natureza diferente. Mas Guilherme não entra em pormenores, remetendo o leitor às suas Glossulae sôbre Platão, onde expôs tal assunto. Sabemos, entretanto, que na primeira redação das Glosas ao Timeu, Guilherme sustentou com Teodorico de Chartres que a Alma do Mundo é o Espírito Santo, que transmite às coisas o ser e o movimento e a alguns a vida, a sensibilidade e o discernimento. A mesma teoria continuou a ser mantida nas Glosas à Consolação da Filosofia. Mas na segunda redação das Glosas ao Timeu, Guilherme aparece reticente sôbre a questão. A Alma do Mundo é um espírito infundido nas coisas, conferindo-lhes a vida e o movimento. Alguns dizem que êle é o Espírito Santo, quod nec negamus nec modo affirmamus.

$\mathrm{Na}$ última obra de Guilherme, o Dragmaticon, não há sinal da Alma do Mundo (115).

Alano de Lille não menciona a Alma do Mundo em suas obras literárias nem em seus escritos teológicos geralmente conhecidos. Acontece, porém, que a medievalista Maria Teresa d'Alverny exumou do pó das bibliotecas um manuscrito anônimo, que pelo estilo e por concordâncias com outras obras de Alano, pode ser-lhe atribuído. Trata-se de um sermão, com mais propriedade, talvez, de uma alocução para estudantes "sôbre a Esfera Inteligível", uma cosmologia fantástica inspirada no Timeu de Platão e na qual aparece com ênfase a Alma do Mundo. O tema do sermão é

\footnotetext{
"Deus como esfera inteligível cujo centro está em tôda a parte e a circunferência em nenhuma" (116).
}

De fato, diz Alano, a forma esférica convém admiràvelmente à essência divina, que é o Alfa e o Ômega, o Princípio e o Fim sem princípio nem fim. Alano distingue então quatro esferas que exprimem os quatro graus do ser e às quais correspondem quatro tipos de conhecimento.

A primeira esfera, sensilis, é êste mundo sensível; a segunda, ymaginabilis, é a matéria primordial; a terceira, rationabilis, é a Alma do Mundo e a quarta, intelligibilis, é a imensidade da divina essência . Os graus do conhecimento que permitem ao homem penetrar nas esferas são, respectivamente: sensus, a percepção das coisas materiais pelos sentidos; ymaginatio, faculdade de representar objetos sensíveis ausentes; ratio, poder de julgar e raciocinar, próprio do homem;

(115). - Sofia Vanni-Rovighi, La FILOSOFIA nel SECOLO XII, pág. 39-40.

(116). - Alanus de Insulis, SERMO de SPHAERA INTELLIGIBILI in ALAIN DE LILLE, TEXTES INEDITS, ed. d'Alverny, pág. 295-306. 
intellectus ou intelligentia, o poder de intuir as Formas puras e que ultrapassa o raciocínio.

Cada esfera é como um palácio ou mansão. Na primeira habitam $y$ chones ou as imagens, correspondentes às idéias divinas, e que foram convertidas em coisas reais. Na segunda habitam as yconie, as formas que servem de modelos às coisas, intermediários entre as idéias e as imagens. Na terceira mansão, a Alma do Mundo, residem as ychome, isto é, as formas abstratas que, livres da corrupção da matéria, florescem em virgindade perpétua. $\mathrm{Na}$ quarta exultam as ydee, as idéias, ou sejam,

\footnotetext{
"as formas exemplares das coisas que, fulgurando na luz da sua pureza engendram a luz da contemplação eterna".
}

A Alma do Mundo, por conseguinte, é a esfera racional, a mansão das formas abstraídas da matéria. E' através da razão que a alma humana atinge o seu palácio,

\footnotetext{
"onde contempla o fogo vivificante, a fonte infatigável, o sol perpétuo que dissipa as trevas da máquina mundana com a luz de sua energia e que esclarece o homem como que por um ôlho interior".
}

Para Platão o mundo é um animal, e sua alma, obra do Demiurgo, é um ser divino. Em Plotino apresenta-se a Alma como divindade que organiza o mundo e the comunica a imortalidade. No contexto das três hipóstases, ela é descrita em têrmos de mundividência teológica, que se prestaria muito bem aos arroubos exegéticos dos doutores cristãos. Da mesma forma, em Macróbio ela surge como divindade que emana de Deus, o ser supremo. Calcídio retorna à linha do pensamento platônico. Só que o Demiurgo é apresentado como Deus, ser absoluto e transcendente, e a Alma do Mundo é considerada como energia cósmica de que Deus se serve para mover e animar os sêres perecíveis .

Entre os Santos Padres, Orígenes, por exemplo, procura cristianizar a Alma do Mundo, identificando-a com o poder e a razão de Deus. Ora, no século XII, esta tendência exegética persiste, renova-se, procurando Abelardo entender o que os filósofos disseram da Alma do Mundo como um enigma que escondesse a verdade cristã do Espírito Santo, que Deus teria revelado assim aos pagãos por intermédio da razão. Isso, porém, foi um esfôrço exagerado para interpretar religiosamente o que só devia ser considerado filosòficamente. Bernardo Silvestre, apesar de seu jôgo com a tríade cósmica e com a Trindade divina, restaura, de fato, a orientação de Calcídio a propósito da Alma do Mundo. Guilherme de Conches trata do tema, 
para abandoná-lo em sua última obra, onde poderia perfeitamente figurar, se ainda mantivesse sua concepção anterior. Por outro lado, em obra rìgidamente ortodoxa e de pura cepa teológica a respeito da Trindade, Ricardo de São Vitor não menciona sequer a questão da Alma do Mundo. A identificação, portanto, desta com o Espírito Santo parece que não passou de tentação muito natural, numa época de renascimento dos estudos filosóficos, para quem se deixava impressionar pelas analogias, muitas vêzes inquietantes, entre doutrinas platônicas e verdades cristãs.

A cosmologia fantastica de Alano de Lille, e na qual figura a Alma do Mundo, parece não ter passado de um revestimento mítico, um típico involucrum, para a concepção que o autor formulou a respeito das escalas do ser e dos graus do conhecimento, concepção que espelha fielmente a de Bernardo de Chartres. Este, segundo informa João de Salisbury (117), admitia a doutrina platônica sôbre os três princípios da realidade: Deus, as Idéias e a matéria. Conforme Platão, são três os princípios que compartilham da verdadeira existência: Deus, a matéria e a idéia. Deus é absolutamente imutável; as idéias e a matéria são, de certo modo, imóveis, mas variam nos efeitos devido à sua ação recíproca. As formas servem de modêlo à matéria, sujeitando-a ao movimento, e também variam, de certo modo, ao entrar em contacto com ela.

A doutrina do famoso Carnotense inspira-se, com certeza, na Carta 58 em que Sêneca explica a Lucílio a divisão dos sêres, segundo Platão (118). Essa carta também representa uma das fontes doutrinárias para os platônicos do século XII.

(Continua) .

(117). - METALOGICUS, PL 199, Lib. IV, cap. 35, c1. 938 B.

(118) . - De acôrdo com Sêneca, Platão divide os sêres em seis classes:

1a. - "quod est", isto é, o conceito, que só o pensamento pode apreender. como as ldélas de homem e de animal;

2a. - "quod eminet et exsuperat omnia.", a saber, Deus;

3a. - "quae proprie sunt", as Idéias, sêres imortais, imutáveis, invioláveis, que possuem existêncla próprla;

4a. - o "eidos", que está para as idéias, como a imagem para o modêlo. Se um escultor, por exemplo, fôr representar vergillo numa estátua, a forma desta é o "eldos", e a forma do modêlo, isto é, o poeta, a Idéia;

5a. - "quae communiter sunt", isto é, homens, animats, coiras;

6a. - "quae quasi sunt", como o espaço e o tempo. Sènèque, LETTRES a LUCILIUS, LVIII, T. I, pág. 301 e seguintes. 